\title{
Não apenas uma ausência material, mas uma grande perda
}

Not just a material absence, but a great loss

\section{Benjamin Israel Kopelman ${ }^{1}$}

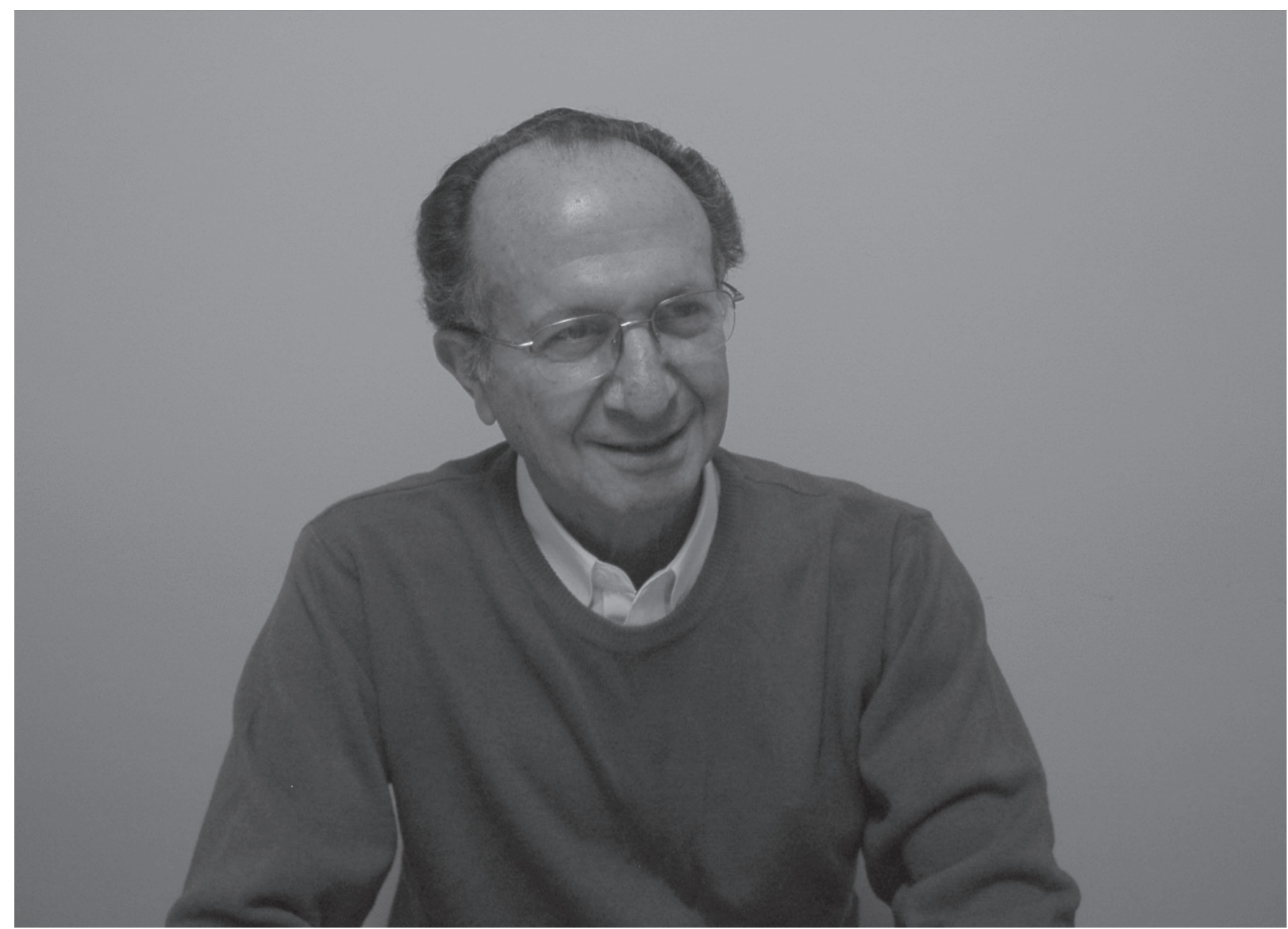

Professor Calil Kairalla Farhat (7/11/1935 - 8/9/2010)

Instituição: Departamento de Pediatria da Escola Paulista de Medicina da Universidade Federal de São Paulo (Unifesp), São Paulo, SP, Brasil

1Professor Titular Aposentado do Departamento de Pediatria da Escola

Paulista de Medicina da Unifesp, São Paulo, SP, Brasil
Endereço para correspondência:

Benjamin Israel Kopelman

Rua Diogo de Faria, 764

CEP 04037-002 - São Paulo/SP

E-mail: neonatal@unifesp.br

Conflito de interesse: nada a declarar

Recebido em: 05/12/2010 
O Calil nos deixou - uma perda inestimável para a Pediatria Brasileira, para seus amigos e familiares. Escrevo sobre a emoção que surge da saudade e da gratidão por um amigo que ocupa um lugar especial em minha memória afetiva.

Conhecemo-nos em 1952, no Colégio Bandeirantes, ambos vindos do interior de São Paulo - ele, de Fernando Prestes, e eu, de Marília - e consolidamos uma amizade que permaneceu para sempre. Estudamos juntos para o vestibular. Somos da mesma turma da Escola Paulista de Medicina (1959) e, com outros colegas, fundamos, em 1962, o Hospital Infantil Sabará, que permanece como referência no atendimento a crianças e adolescentes.

Nossas famílias sempre estiveram juntas, partilhamos muitas alegrias, comemorações, momentos de angústia e de sofrimento, nos quais sua presença sempre acrescentou esperança, alento e solidariedade.

Foi Professor Associado de Pediatria da Faculdade de Ciências Médicas da Santa Casa de São Paulo e Professor Titular de Moléstias Infecciosas da Faculdade de Medicina de Marília, mas foi na nossa querida Escola Paulista de Medicina que desenvolveu a maior parte do seu brilhante currículo. Honrou a instituição e contribuiu para torná-la um centro de excelência nacional e internacional. Foi Doutor no ano de 1973, Livre-docente em 1973 e Professor Titular do Departamento de Pediatria em 1982.

Criou os primeiros cursos de Pós-Graduação em Infectologia Pediátrica e Vacinas do país (1980), sendo coordenador desses cursos até o ano de 2000. Criou a primeira disciplina de Infectologia Pediátrica no país (1984), a qual chefiou por vários anos, tendo orientado dezenas de pós-graduandos, mestres e doutores. Teve grande participação societária, presidindo o Departamento de Infectologia da Sociedade Brasileira de Pediatria nos anos de 1992-1993 e de 1997-1998. Foi mentor e um dos fundadores da Sociedade Latino-Americana de Infectologia Pediátrica (SLIPE), que presidiu nos anos de 1998-1999, e da World Society of Pediatric Infectious Diseases.

Os vários problemas de saúde jamais impediram sua profícua existência. Tinha um grande senso de dever e amor à vida. Proferiu 1.524 conferências e aulas, sendo 1.244 no Brasil e 280 no exterior. Publicou dez livros, a maioria reeditada. Escrevemos juntos o livro Infecções Perinatais, pela editora Atheneu - duas edições que dedicamos às nossas esposas e filhas. Escreveu 145 capítulos de livros no Brasil e no exterior. Participou de mais de 140 eventos no Brasil, apresentando 320 trabalhos científicos, e de 138 eventos no exterior, apresentando 34 trabalhos. Recebeu 67 títulos honoríficos e prêmios no Brasil e no exterior. Participou de 175 bancas examinadoras na Escola Paulista de Medicina da Universidade Federal de São Paulo e em diversas escolas médicas de todo o país.

Membro Titular da Academia Brasileira de Pediatria, o Calil foi meu padrinho e fez o discurso de posse quando fui eleito para ocupar a cadeira de número 10, cujo patrono é o Professor Pedro de Alcântara.

Era dedicado à sua família, da qual muito se orgulhava, e agregava amigos com generosidade. Nos últimos anos, foi acometido por grave doença, mas não se reduziu à mesma, mantendo sempre seu humor e sorriso inconfundíveis. Jamais teve atitude pessimista diante das adversidades. Tinha uma fé inquebrantável e a crença de que nos desenvolvemos diante de alguém mais elevado, em um caminho de espiritualidade. Conhecia o valor moral do bem e da caridade e cultivava o bom instinto humano derivado de valores essenciais existentes em cada um de nós.

Cumpriu uma bela missão na terra e muitos esperam reencontrá-lo um dia, como era a sua crença. Não é apenas uma ausência material, mas uma grande perda: Professor Calil Kairalla Farhat (7/11/1935 - 8/9/2010). 